\title{
APPLICATION OF CONTINUOUS FLOW ELECTROPHORESIS TO THE STUDY OF THE BLOOD COAGULATION PROTEINS AND THE FIBRINOLYTIC ENZYME SYSTEM. I. NOR- MAL HUMAN MATERIALS ${ }^{1}$
}

\author{
By JESSICA H. LEWIS, DENNY WALTERS, PAUL DIDISHEIM, ${ }^{2}$ AND \\ WILLIAM R. MERCHANT \\ (From the Department of Medicine, University of Pittsburgh, and the Veteran's Administra- \\ tion Hospital, Pittsburgh, Pa.)
}

(Submitted for publication April 2, 1958; accepted May 8, 1958)

Continuous flow filter paper electrophoresis, as developed by Svensson and Brattsen (1), Grassmann and Hannig (2-4) and Durrum (5), offers a method of plasma fractionation in which protein denaturation appears minimal. This study involves the testing of such fractions for biological activity in various coagulation systems. With the exception of fibrinogen, the coagulation proteins are present in plasma in minute amounts which, at the present time, can be assayed only by their activities in specific clotting systems. Many of these coagulation factors are readily denatured; thus, rigid control with particular attention to temperature is necessary to obtain good recovery of biological activity.

Previous electrophoretic studies concerning distribution of plasma coagulation proteins have employed paper electrophoresis with elutions from cut strips. Owen and McKenzie (6) found prothrombin to coincide with $\alpha_{2}$ globulin, proconvertin (stable conversion factor) with $\beta$ globulin, proaccelerin (labile conversion factor) in a variable area between $\gamma$ and $\beta$ peaks, antithrombin between $\beta$ and $\alpha_{2}$, and fibrinogen remaining at the point of application. Using the same technique, Frick and Hagen ( 7 ) found Hageman factor activity in a fraction located between $\beta$ and $\gamma$ globulin. On the other hand, the electrophoretic mobility of purified prothrombin was described by Seegers, McClaughry, and Fahey (8) as approximately equivalent to that of $\alpha_{1}$ globulin. The

1 This investigation was supported in part by a research grant (H-2254) from the Division of Research Grants of the National Institutes of Health, United States Public Health Service.

2 Part of this investigation was carried out during the tenure of a postdoctorate fellowship, Life Insurance Medical Research Fund. present studies show considerable agreement with these findings.

In Table I are listed the coagulation proteins whose existence seems well established' today. Included in the table are the abbreviations used in the subsequent text and charts together with some of the synonyms.

\section{METHODS}

Electrophoretic technique. Principles of continuous flow electrophoresis on filter paper are well described by Block, Durrum, and Zweig (9). The two instruments ${ }^{3}$ employed in these studies were placed in a cold room with its temperature regulated to approximately $8^{\circ} \mathrm{C}$. The circulating buffer was further refrigerated, entering the instrument at $1^{\circ} \mathrm{C}$. All the runs described in this communication utilized a filter paper curtain, Schleicher and Schuell 470; a barbital buffer, $\mathrm{pH} 8.6$; ionic strength, 0.02 ; and a power supply adjusted to 50 m.a. and 720 volts. Under these conditions the thermocouple readings on the curtain during electrophoresis were $18^{\circ} \mathrm{C}$. Before starting electrophoresis it was important to allow the instrument to stabilize for at least

TABLE I

Coagulation proteins

AHF Antihemophilic Factor A-Factor VIII

PTC Plasma thromboplastin component-Factor IXChristmas factor-Antihemophilic Factor B

PTA Plasma thromboplastin antecedent-Antihemophilic Factor C

HAG Hageman factor-Antihemophilic Factor D

ProA Proaccelerin-Factor V-labile factor-AcG

ProC , Proconvertin-stable factor

A) SPCA, Factor VII

B) Stuart

ProT Prothrombin-Factor II

FIB Fibrinogen-Factor I

AntiT Antithrombin

H Heparin cofactor

Glass Glass factor

ProF Profibrinolysin

AntiF Antifibrinolysin

3 Beckman/Spinco Division. 


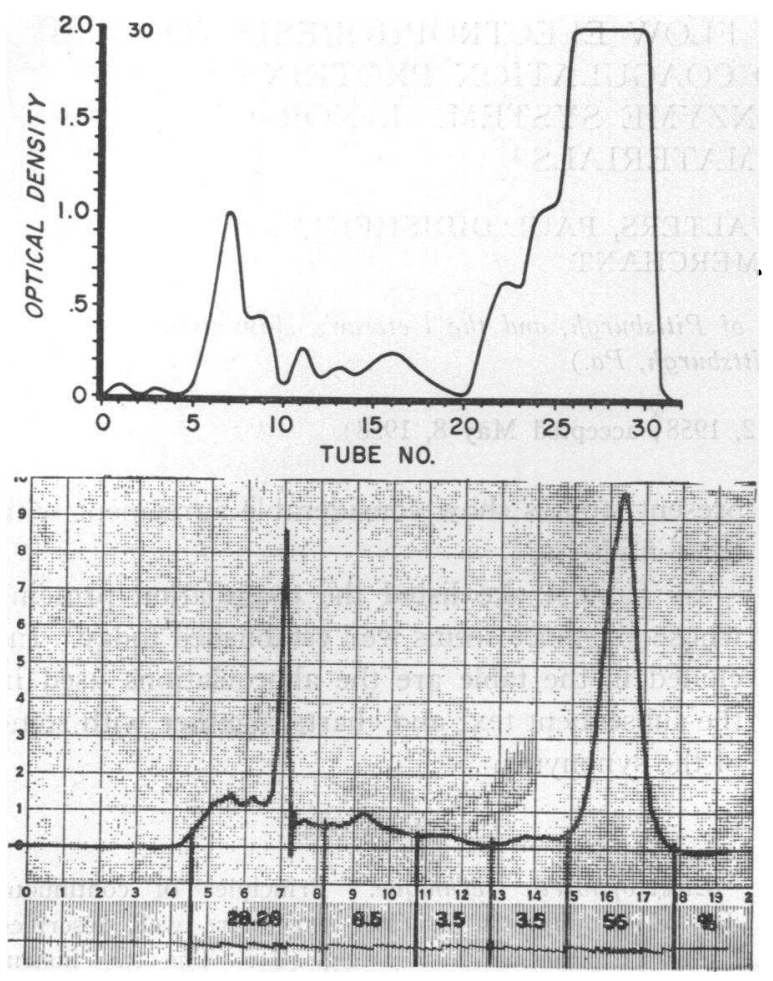

Fig. 1. Comparison of Curtain and Paper Strip ELECTROPHORESIS

six hours with buffer circulating and current applied. Plasma or its fractions were rapidly prepared, utilizing refrigerated centrifugation and dialyzing against the barbital buffer for only two hours. The feed rate was adjusted so that approximately $15 \mathrm{ml}$. of material was fractionated during the electrophoretic runs, which were usually limited to 18 hours. Depending on the rate of buffer flow down the curtain, the material separated and collected in each of 32 tubes was diluted with 5 to $10 \mathrm{ml}$. of buffer.

Ninhydrin, $0.5 \mathrm{ml}$, was added to $0.5 \mathrm{ml}$. aliquots from each tube. The tubes containing this mixture were plugged with cotton and heated for 20 minutes in a boiling water bath. Following cooling, $4 \mathrm{ml}$. of 50 per cent propanol was added and the optical densities were read at $540 \mathrm{~m} \mu$ in a spectrophotometer. Plotting the optical density of each tube on the ordinate, with tube numbers on the abscissa, gave a rather quick semiquantitative estimate of the concentration and distribution of the protein in the tubes. Figure 1 shows that the ninhydrin optical density of each tube plotted as a continuous curve closely resembles the analytrol scan from the paper electrophoresis of the same plasma.

Although the runs were limited to 18 hours, reproducibility during a single run was determined by comparing the ninhydrin optical density of samples at 16 and 42 hour intervals (Figure 2).

Following completion of the run, the curtains were removed, dried in an oven $\left(110^{\circ} \mathrm{C}\right.$.) and dyed with brom- phenol blue. Distribution of the proteins could be further evaluated by the dye pattern.

Paper strip electrophoresis technique was the hanging strip method of Durrum (9). The experimental conditions were Schleicher and Schuell $2043 \mathrm{~A} \mathrm{mgl}$ filter paper, eight strips per cell $3.0 \times 30.6 \mathrm{~cm}$., $0.02 \mathrm{ml}$. of material applied at apex, barbital buffer $\mathrm{pH} 8.6, \Gamma / 20.05$, 16 hour duration, constant current of 4 m.a., and staining with bromphenol blue. The strips were analyzed by analytrol with neutral density filter calibrated $7.4 \mathrm{~cm}$.

Assay of coagulation factors. With the exception of fibrinogen, the coagulation proteins were assayed in systems which attempted to be as specific as possible for the factor in question. For example, antihemophilic factor (AHF) was assayed by measuring the ability of a given fraction (or plasma) to shorten the recalcification time and improve the prothrombin consumption of a standard plasma (stored, frozen, at $-20^{\circ}$ C.) from a severe hemophiliac. Obviously the recalcification time can be shortened by materials other than AHF (thrombin, thromboplastin, SPCA (10), certain cellulose products, powdered glass, and so forth). Effects of such nonspecific coagulants could not be evaluated completely, but appeared to be minor in these experiments.

The clotting activity entitled "proconvertin" in this report includes the activities of two chemically related factors: SPCA or Factor VII $(11,12)$ and Stuart factor (13).

"Glass factor" is a term used to express the ability of certain fractions or of plasma treated with glass to shorten the recalcification time and improve prothrombin consumption of normal plasma prepared and recalcified in siliconed tubes.

Tubes containing fractions were kept thoroughly chilled and tests carried out as rapidly as possible. The dialyzed

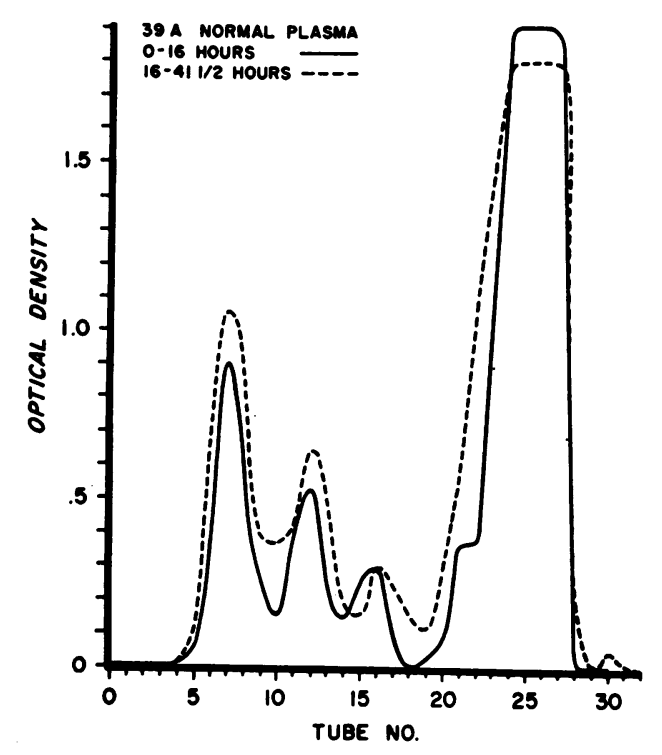

Fig. 2. Comparison of 16 ANd $41 \frac{1}{2}$ Hour Ninhydrin Optical Density Curves 
plasma remaining in the reservoir was used as the control and arbitrarily defined as containing 100 units of each factor tested. Attempts to quantitate the recovery of each factor were only partially successful as exact measurement of volume of plasma fractionated (i.e., volume applied minus volume remaining on curtain) was difficult. In addition, assays such as AHF, plasma thromboplastin component (PTC), and Hageman factor have an error of approximately plus or minus 20 per cent in the range of 50 to 150 per cent of normal and plus or minus 10 per cent in the range of 1 to 50 per cent of normal. Thus most of the charts present the recovery of each factor in a semiquantitative fashion. The blocked-in areas indicate tubes containing activity comparable to from 2.5 to 100 per cent of that found in the mother plasma. When serum or chemical fractions were studied, normal plasma was used as the control.

Most of the assay methods have been previously described (14): fibrinogen; prothrombin (Method 1); proconvertin; proaccelerin (Method 1); antihemophilic factor (AHF) ; plasma thromboplastin component (PTC); and Hageman factor. In addition the following tests were included :

1. "Glass factor" assay. In siliconed tubes, mix 0.05 $\mathrm{ml}$. fraction with $0.2 \mathrm{ml}$. citrated normal plasma prepared by using all siliconed glassware with centrifugation of blood at $2000 \mathrm{rpm}$ for 10 minutes. Measure clotting time after addition of $0.2 \mathrm{ml}$. $0.025 \mathrm{M}$ calcium chloride. After one hour at $37^{\circ} \mathrm{C}$. add $0.05 \mathrm{ml}$. $0.1 \mathrm{M}$ sodium oxalate, wind out the clot and measure residual prothrombin. The presence of a "glass factor," i.e., a material capable of hastening coagulation of normal plasma in silicone, was evidenced by marked shortening of clotting time and lessening of residual prothrombin.

2. PTA assay (plasma thromboplastin antecedent). Sufficient material was available for assay of PTA in only one run. The system used was identical to that used for AHF, PTC, Hageman and glass factors : $0.2 \mathrm{ml}$. of deficient plasma 4 is mixed with $0.05 \mathrm{ml}$. fraction or plasma dilution, and recalcified with $0.2 \mathrm{ml}$. of $0.025 \mathrm{M}$ $\mathrm{CaCl}_{2}$. The clotting time $\left(37^{\circ} \mathrm{C}\right.$.) is recorded and after one hour $0.05 \mathrm{ml}$. of $0.1 \mathrm{M}$ sodium oxalate is added, the clot wound out and the residual prothrombin determined.

3. Antithrombin time. Mix $0.1 \mathrm{ml}$. fraction plus 0.1 ml. 0.85 per cent sodium chloride plus $0.1 \mathrm{ml}$. human thrombin; incubate mixture 30 minutes at $37^{\circ} \mathrm{C}$.; remove clot, if any; determine clotting time on addition of $0.1 \mathrm{ml}$. bovine fibrinogen.

4. Heparin cofactor time. Mix $0.1 \mathrm{ml}$. fraction plus $0.1 \mathrm{ml}$. heparin ( 5 units per $\mathrm{ml}$.) plus $0.1 \mathrm{ml}$. fibrinogen; determine clotting on addition of $0.1 \mathrm{ml}$. human thrombin.

5. Control for 3 and 4 . Mix $0.1 \mathrm{ml}$. fraction plus 0.1 ml. 0.85 per cent sodium chloride plus $0.1 \mathrm{ml}$. fibrinogen; determine clotting on addition of $0.1 \mathrm{ml}$. human thrombin.

Preparation of human thrombin. Suspend $0.1 \mathrm{ml}$. washed human platelets (source of proaccelerin) plus 0.1 $\mathrm{ml}$. human brain suspension $(0.6 \mathrm{Gm}$. per $10 \mathrm{ml}$. saline)

4 PTA deficient plasma was obtained through the kindness of Dr. Robert Rosenthal.

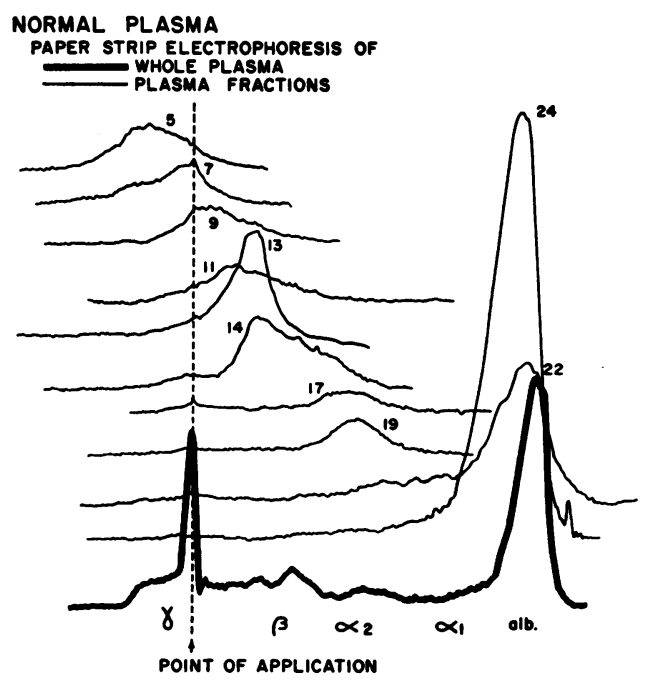

Fig. 3. Analytrol Scans of Paper Strip Electrophoretic Patterns of Fractions From Curtain Electrophoresis of Normal Plasma

in about $5 \mathrm{ml}$. saline, centrifuge at $20,000 \mathrm{rpm}$ for $15 \mathrm{~min}$ utes, discard supernatant. Add $0.5 \mathrm{ml}$. $\mathrm{BaSO}_{4}$ plasma eluate, $0.5 \mathrm{ml}$. imidazole buffer, $3.3 \mathrm{ml}$. saline and 0.5 ml. $0.1 \mathrm{M}$ calcium chloride. After 15 minutes incubation add $0.5 \mathrm{ml}$. $0.1 \mathrm{M}$ sodium oxalate and recentrifuge at 20,000 rpm for 15 minutes. Discard sediment. The $\mathrm{BaSO}_{4}$ eluate was prepared by mixing $100 \mathrm{mg}$. BaSO, per ml. human plasma, sedimenting and washing the $\mathrm{BaSO}_{4}$ and eluting prothrombin (plus other proteins) with one-eighth volume of $0.2 \mathrm{M}$ sodium citrate.

Assay of fibrinolytic factors. Preliminary and simplified assays for components of the fibrinolytic enzyme system were undertaken.

1. Fibrinolysin. Mix $0.1 \mathrm{ml}$. fraction plus $0.1 \mathrm{ml}$. saline plus $0.1 \mathrm{ml}$. 1 per cent bovine fibrinogen ${ }^{5}$ plus $0.1 \mathrm{ml}$. bovine thrombin 6 (20 units per $\mathrm{ml}$.).

2. Proactivator or profibrinolysin. Mix $0.1 \mathrm{ml}$. fraction plus $0.1 \mathrm{ml}$. streptokinase 7 (200 units per $\mathrm{ml}$.) plus $0.1 \mathrm{ml}$. bovine thrombin plus 0.1 bovine fibrinogen.

3. Profibrinolysin. Same as 2 but substitute human for bovine thrombin.

4. Antifibrinolysin. Mix $0.1 \mathrm{ml}$. fraction plus $0.1 \mathrm{ml}$. active dog fibrinolysin (15); incubate 60 minutes at $37^{\circ} \mathrm{C}$., plus $0.1 \mathrm{ml}$. bovine thrombin plus $0.1 \mathrm{ml}$. bovine fibrinogen.

\section{Materials}

Early experiments were attended by numerous technical difficulties and are excluded from the series. Satisfactory normal experiments have included 24 on citrated plasma, 2 on serum, 3 on $\mathrm{BaSO}_{4}$ treated oxalated plasma,

5 The Armour Laboratories.

6 Thrombin, Topical, supplied through the kindness of Parke, Davis and Co.

7 Varidase ${ }^{\circledR}$, supplied through the kindness of Lederle Laboratories Division, American Cyanamid Company. 

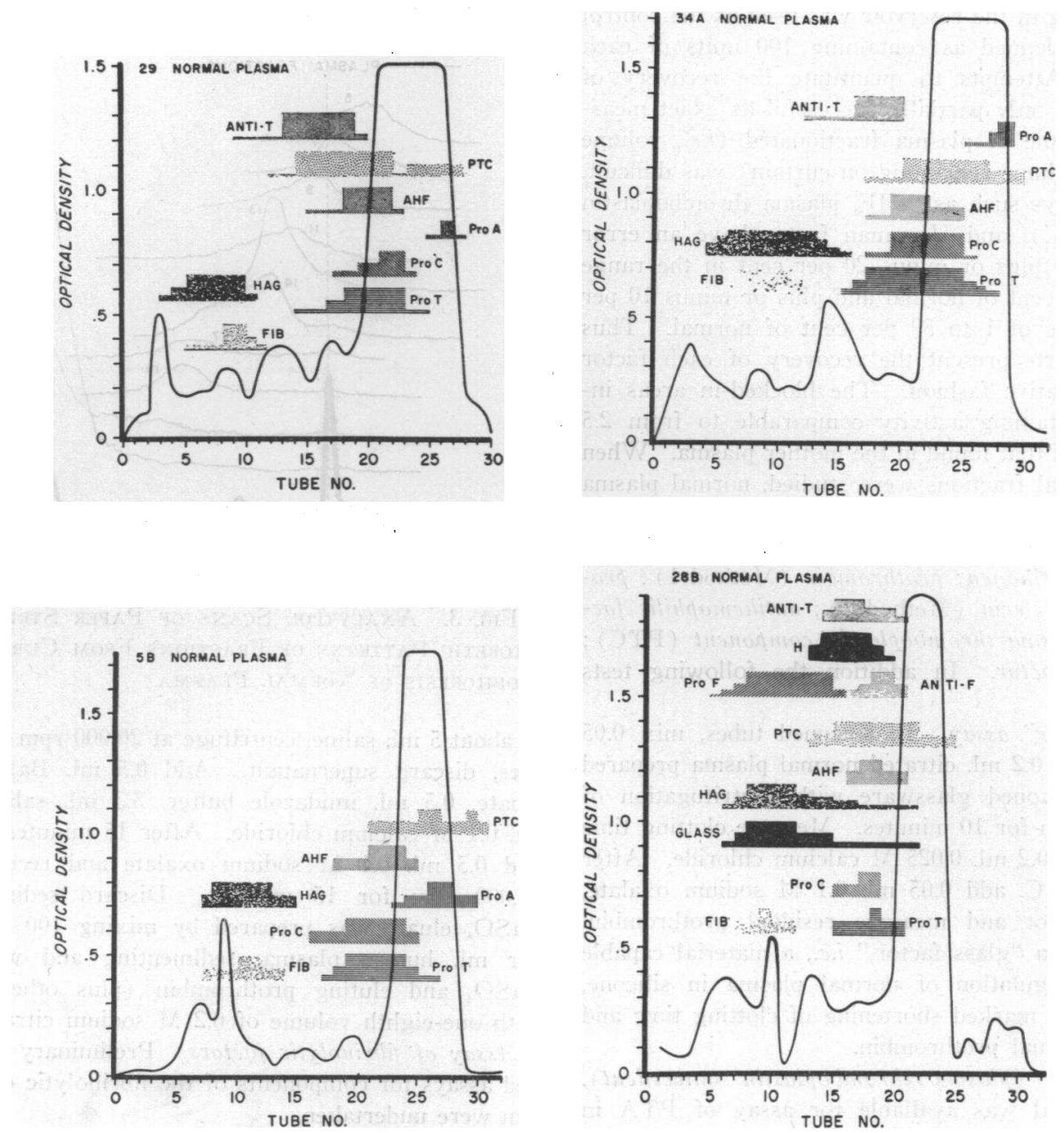

Fig. 4. Distribution of Coagulation Proteins After Curtain Electrophoresis of Normal Plasma

2 on $\mathrm{BaSO}_{4}$ treated serum and 7 on various chemically prepared fractions.

$\mathrm{BaSO}_{4}$ eluate. $100 \mathrm{ml}$. normal oxalated plasma was mixed with $10 \mathrm{Gm}$. BaSO (Baker) for 10 minutes at room temperature; the mixture centrifuged 10 minutes at $4500 \mathrm{rpm}$; the sedimented $\mathrm{BaSO}$, washed twice with 0.85 per cent $\mathrm{NaCl}$ and twice with distilled water, remixing and recentrifuging each time; and finally eluted by mixing with $15 \mathrm{ml} .0 .2 \mathrm{M}$ sodium citrate and centrifuging.

Ammonium sulfate fractions. $\mathrm{BaSO}_{4}$ treated plasma (as prepared above) was fractionated by addition of saturated ammonium sulfate solution (room temperature). The precipitates, appearing after 28 per cent saturation and after sufficient additional ammonium sulfate solution was added to bring the concentration to 35 per cent, were collected by centrifugation and each was dissolved in one-fifth the plasma volume of distilled water. The supernatant was dialyzed alternately in distilled water and 25 per cent PVP (polyvinylpyrrolidone) until the volume and ionic concentration (as estimated by specific resistance measurements) returned to that of the original plasma. All fractions were dialyzed against barbital buffer before electrophoresis.

Fibrinogen. A human plasma fraction, Fibrinitole, was provided through the courtesy of Ortho Research Institute.

\section{RESULTS}

Normal plasma. Comparison of curtain with paper strip electrophoresis

Samples from each tube from a number of curtains were analyzed by paper strip electrophoresis to determine mobility and homogeneity of the protein content. Figure 3 shows the results of a typical experiment. Commonly, tubes 1 to 13 contained $\gamma$ globulin; 14 to $15, \beta$ globulin; 17 to 20 , 
$\alpha_{2}$ globulin. $\alpha_{1}$ globulin and albumin appeared in the large peak usually found between tubes 20 to 30. Not infrequently either one or two "pre-albumin" peaks were found in tube areas 30 to 32 .

\section{Distribution of coagulation factors}

Figure 4 illustrates the distribution of coagulation factors among the various fractions in four runs on different normal plasmas. Fibrinogen, Hageman factor, "glass factor" and profibrinolysin were found in the $\gamma$ area; heparin cofactor and antithrombin in the $\beta$ to $\alpha_{2}$ areas; prothrombin, proconvertin, AHF, PTC and antifibrinolysin in the $\alpha_{2}$ to $\alpha_{1}$ areas and proaccelerin in the albumin area.

\section{Recovery of coagulation factors}

Total recovery of fibrinogen, prothrombin, proconvertin, and proaccelerin was estimated in a number of experiments. Fibrinogen recovery was used as a criteria of a satisfactory run and if the total amount of fibrinogen found in all of the tubes was less than 20 per cent of that present in the volume of plasma electrophoresed, the tubes were discarded. Fibrinogen recovery varied from 20 to 106 per cent; prothrombin from 46 to 110 per cent ; proconvertin from 26 to 80 per cent and proaccelerin from 0 to 28 per cent.

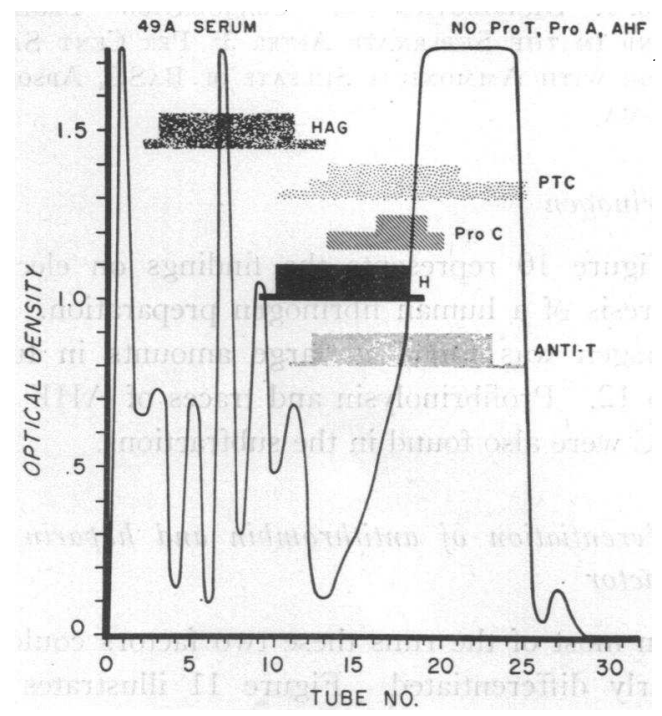

Fig. 5. Distribution of Coagulation Proteins after Curtain Electrophoresis of Normal Serum

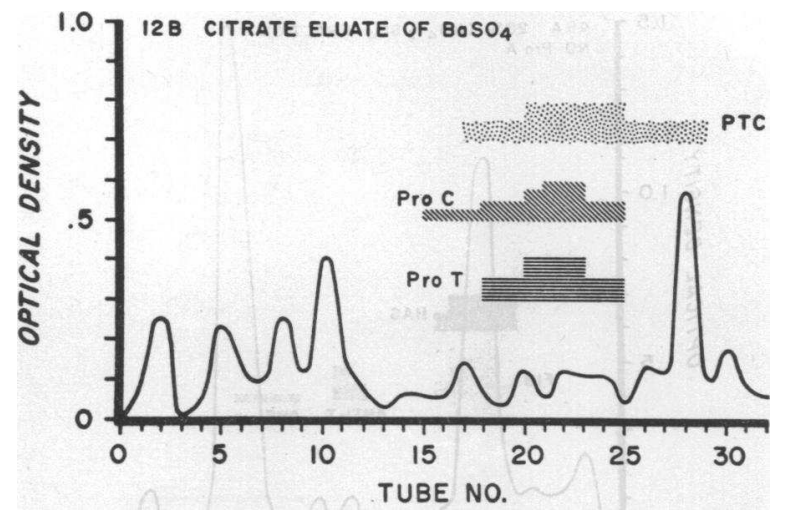

Fig. 6. Distribution of Coagulation Proteins after Curtain Electrophoresis of the BaSO, Eluate of Normal Plasma

\section{Normal serum}

Figure 5 illustrates the results in a typical normal serum run. The protein concentration per tube was high and is reflected in the peaks found in tubes 2 to 13 . As expected no fibrinogen was found. In this run (49A) prothrombin, proaccelerin and AHF were not detectable in the fractions although the whole serum contained 10 per cent AHF and 1 per cent prothrombin as compared to fresh plasma. In other serum runs traces of prothrombin have been found. Hageman factor, PTC and proconvertin appeared in their usual places. Heparin cofactor activity could be clearly differentiated from antithrombin activity although the two overlapped in a number of tubes.

\section{$\mathrm{BaSO}_{4}$ plasma}

Three experiments on $\mathrm{BaSO}_{4}$ adsorbed plasma showed no prothrombin, proconvertin or PTC, but the other coagulation proteins in their usual places. In one run, fractions were assayed for Hageman factor, glass factor and PTA. The three activities were found in the same fractions.

\section{Plasma fractions}

Certain plasma fractions prepared by chemical means were further studied and subfractionated by curtain electrophoresis.

\section{$\mathrm{BaSO}_{4}$ eluate}

Tests on the whole fraction showed the presence of prothrombin, proconvertin, and PTC and 


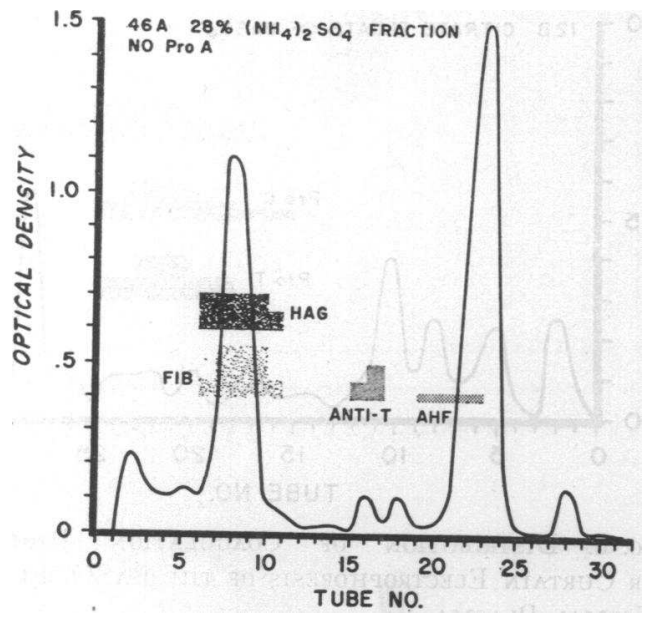

Fig. 7. Distribution of Coagulation Proteins Found in a 28 Per Cent Ammonium Sulfate Fraction of BaSO, Adsorbed Plasma

these same materials were present in the electrophoretically prepared subfractions (Figure 6). As would be anticipated from their appearance in the same areas in plasma, no clear separation of these three components was achieved at this $\mathrm{pH}$.

\section{Ammonium sulfate fractions}

Figures 7, 8 and 9 illustrate the results on continuous flow electrophoresis. The 28 per cent fraction appears to contain primarily $\gamma$ globulin with a late peak in the albumin area. Hageman

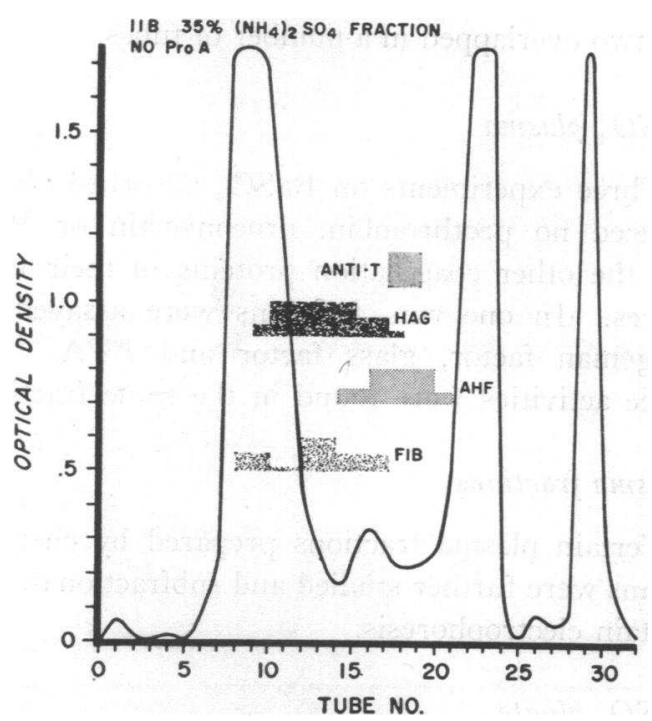

Fig. 8. Distribution of Coagulation Proteins Found in a 35 Per Cent Ammonium Sulfate Fraction of $\mathrm{BaSO}_{4}$ Adsorbed Plasma factor, fibrinogen, antithrombin and a trace of AHF were found. The 35 per cent fraction showed three distinct peaks, clearly visible on the stained curtain as well as in the protein pattern. Again, Hageman factor, fibrinogen, AHF and antithrombin were found. The supernatent from the 35 per cent fraction appears to contain primarily albumin, with smaller amounts of other components. The only coagulation factor found was the Hageman factor, present as usual in the $\gamma$ area. None of the subfractions contained appreciable amounts of proaccelerin, which presumably deteriorated during the procedures.

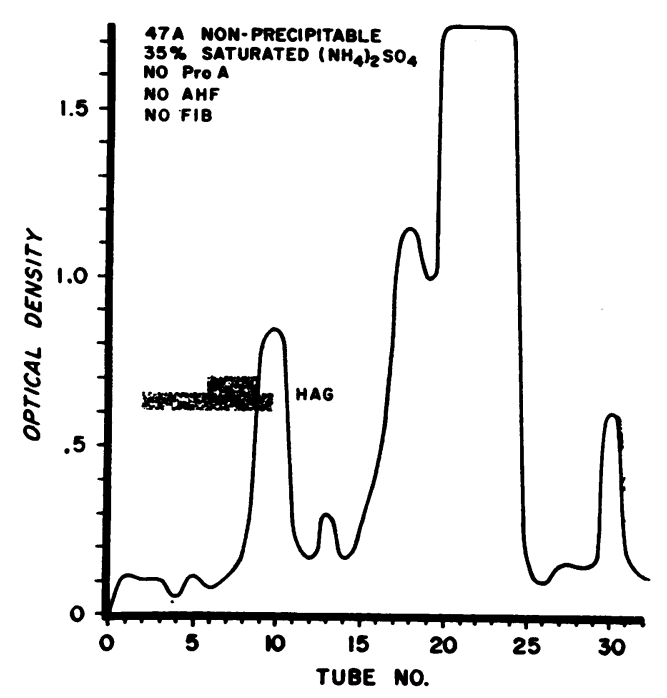

Fig. 9. Distribution of Congulation Proteins Found in the Supernate After 35 Per Cent Saturation with Ammonium Sulfate of BaSO, Adsorbed Plasma

\section{Fibrinogen}

Figure 10 represents the findings on electrophoresis of a human fibrinogen preparation. Fibrinogen was found in large amounts in tubes 7 to 12. Profibrinolysin and traces of $\mathrm{AHF}$ and PTC were also found in the subfractions.

\section{Differentiation of antithrombin and heparin co- factor}

In most of the runs these two factors could be clearly differentiated. Figure 11 illustrates the detailed tests in a run on $\mathrm{BaSO}_{4}$ treated plasma (29B). The control tests, in which each fraction 
plus saline plus fibrinogen was clotted with thrombin, showed approximately the same clotting time in all tubes. If, instead, the fractions were tested for antithrombin by first incubating with thrombin and then clotting with added fibrinogen, tubes 19 to 28 could markedly inhibit the thrombin. However, if each fraction was mixed with heparin and fibrinogen, then clotted with thrombin, tubes 17 to 24 showed marked heparin potentiating effect. Thus, although there was an overlap, at least two tubes on each end showed primarily a single activity.

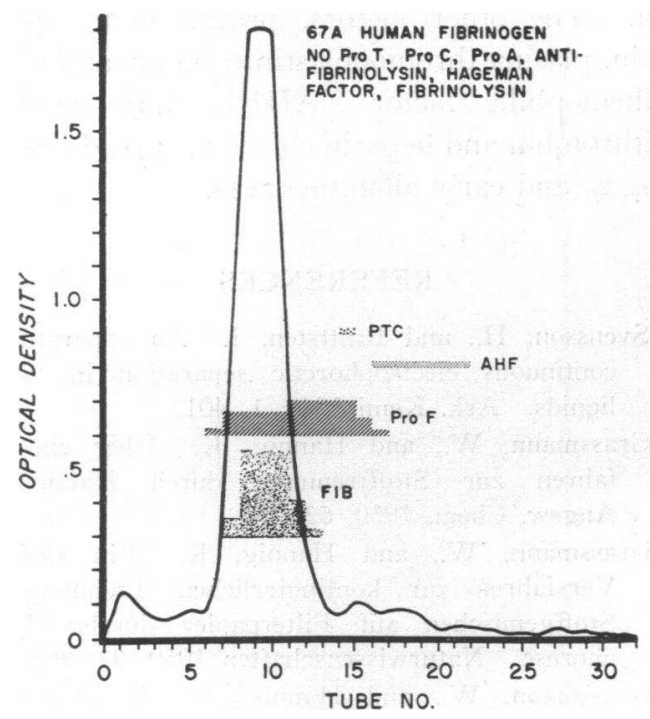

Fig. 10. Distribution of Coagulation Proteins From a Plasma Fraction High in Fibrinogen Content

\section{Fibrinolytic enzyme system}

Figure 12 shows details of the tests for components of this system in a typical plasma run (66A). The test for fibrinolysin shows that none of the fractions were able to lyse the clot and therefore must be considered devoid of active fibrinolysin. Antifibrinolysin was clearly demonstrated in tubes 15 to 25 . Profibrinolysin, tested by mixture of streptokinase and fractions in a bovine thrombin-fibrinogen clot, was present in tubes 5 to 16 . As it might be argued that this test was actually measuring the presence of a streptokinase sensitive activator system (16) in the human fractions which, in turn, activated bovine profibrinolysin present in the fibrinogen or

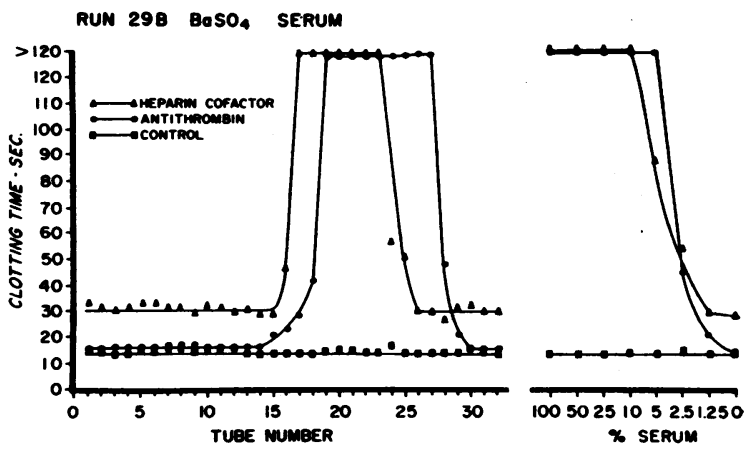

Fig. 11. Assay of Heparin Cofactor and AntiTHROMBIN

thrombin, an additional test was run in which human thrombin was substituted for the bovine thrombin. This human thrombin should provide a constant supply of the activator system so that the profibrinolysin in the fibrinogen of all tubes would be activated. The results (not illustrated) showed lysis times in tubes 5 to 16 identical to those found with bovine thrombin. All of the other tubes did show a slow lysis (40 to 60 minutes) indicating activation of a trace of contaminating profibrinolysin present in either the thrombin or the fibrinogen.

\section{DISCUSSION}

These experiments demonstrate the usefulness of the continuous flow electrophoretic technique in fractionating plasma proteins. Although in this early stage in the use of this technique, complete separation of the various clotting factors has not been achieved, yet their recovery in apparently undenatured form and in volume adequate for many studies suggests that the general principles

RUN CSA MOMMAL PLASMA FIENMOCYTIC ENZYME SYSTEM

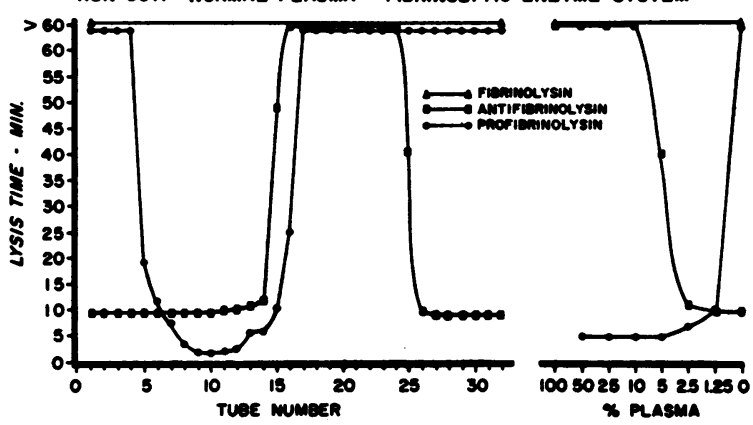

Fig. 12. Assay of Fibrinolysin, Profibrinolysin AND ANTIFIBRINOLYSIN 
of flow-electrophoresis are worth pursuit. Current experiments include variation in buffer and in curtain material.

The categorization of proteins into albumins, $\alpha, \beta$ and $\gamma$ globulins, is descriptively useful but applies to only one characteristic-molecular (or aggregate) mobility in an electrical field. In common usage it is even restricted to a particular buffer system. When such terminology is applied to the coagulation proteins, fibrinogen, Hageman factor, "glass factor" and profibrinolysin appear to be $\gamma$ globulins, proaccelerin an albumin, and the rest mixtures of $\alpha_{1}, \alpha_{2}$, some albumin and some $\beta$. In these preliminary stages, such spreading does not necessarily indicate that a given biological activity is associated with protein molecules of different size, configuration or charge.

Certain interesting and useful observations were made. The distribution of glass factor activity coincided with Hageman factor, suggesting that these may be identical. The identification of glass factor with Hageman factor has been previously suggested by Ratnoff and Rosenblum (17). It was possible to assay for PTA activity in only one run. In this experiment PTA activity appeared to coincide with Hageman factor and with "glass factor" activities. This close association suggests that these apparently different disorders (Hageman trait and PTA deficiency) may be closely related. It is hoped to pursue this matter by fractionation of both types of deficient plasmas. Activities of heparin cofactor and antithrombin were shown to be distinct.

Preliminary tests for the fibrinolytic enzyme system showed the presence of profibrinolysin and antifibrinolysin. No real indication of the presence of a proactivator-activator mechanism (16) through which streptokinase activates human profibrinolysin could be found. If such a system does exist both the proactivator and profibrinolysin must coexist in the same fractions.

\section{SUM MARY}

1. Continuous flow paper electrophoresis allows the fractionation of approximately $15 \mathrm{ml}$. of plasma or other material into 32 fractions. The volume fractionated and the distribution of fractions is dependent upon such technical considerations as applied voltage, buffer flow, wick flow and plasma flow. All experiments in this study employed barbital buffer $\mathrm{pH} 8.6$, ionic strength 0.02 , and special cooling technique.

2. Content of coagulation proteins in each fraction was determined by measuring their various biological activities. High recovery of such activities suggested that little or no denaturation had occurred.

3. Fibrinogen, profibrinolysin, Hageman factor, plasma thromboplastin antecedent (PTA) and "glass factor" appeared in the $\gamma$ globulin area. The latter three are similar in their fraction distribution. Proaccelerin appeared in the albumin area. The other factors, prothrombin, proconvertin, plasma thromboplastin component (PTC), antihemophilic factor (AHF), antifibrinolysin, antithrombin and heparin cofactor, spread over the $\beta, \alpha_{2}, \alpha_{1}$ and early albumin areas.

\section{REFERENCES}

1. Svensson, H., and Brattsten, I. An apparatus for continuous electrophoretic separation in flowing liquids. Ark. Kemi 1949, 1, 401.

2. Grassmann, W., and Hannig, K. Utber ein Verfahren zur Stofftrennung durch Kataphorese. Angew. Chem. 1950, 62, 170.

3. Grassmann, W., and Hannig, K. Ein einfaches Versfahren zur kontinuierlichen Trennung von Stoffgemischen auf Filterpapier durch Electrophorese. Naturwissenschaften 1950, 37, 397.

4. Grassmann, W., and Hannig, K. Trennung von Stoffgemischen auf Filtrierpapier durch Ablenkung im elektrischen Feld. Hoppe-Seylers Z. physiol. Chem. 1953, 292, 32.

5. Durrum, E. L. Continuous electrophoresis and ionophoresis on filter paper. J. Amer. chem. Soc. 1951, 73, 4875.

6. Owen, C. A., Jr., and McKenzie, B. F. Application of paper electrophoresis to separation of bloodclotting factors. J. appl. Physiol. 1954, 6, 696.

7. Frick, P. G., and Hagen, P. S. Severe coagulation defect without hemorrhagic symptoms caused by a deficiency of the fifth plasma thromboplastin precursor. J. Lab. clin. Med. 1956, 47, 592.

8. Seegers, W. H., McClaughry, R. I., and Fahey, J. L. Some properties of purified prothrombin and its activation with sodium citrate. Blood 1950, 5, 421.

9. Block, R. J., Durrum, E. L., and Zweig, G. A Manual of Paper Chromotography and Paper Electrophoresis. New York, Academic Press, Inc., 1955.

10. Alexander, B., Goldstein, R., and Landwehr, G. The prothrombin conversion accelerator of serum (SPCA): Its partial purification and its 
properties compared with serum Ac-globulin. J. clin. Invest. 1950, 29, 881.

11. Alexander, B., Goldstein, R., Landwehr, G., and Cook, C. D. Congenital SPCA deficiency: A hitherto unrecognized coagulation defect with hemorrhage rectified by serum and serum fractions. J. clin. Invest. 1951, 30, 596.

12. Owren, P. A. Prothrombin and accessory factors. Amer. J. Med. 1953, 14, 201.

13. Hougie, C., Barrow, E. M., and Graham, J. B. Stuart clotting defect. I. Segregation of an hereditary hemorrhagic state from the heterogeneous group heretofore called "stable factor" (SPCA, proconvertin, Factor VII) deficiency. J. clin. Invest. 1957, 36, 485.
14. Lewis, J. H., and Didisheim, P. Differential diagnosis and treatment in hemorrhagic disease. Arch. intern. Med. 1957, 100, 157.

15. Lewis, J. H., and Ferguson, J. H. Studies on a proteolytic enzyme system of the blood. IV. Activation of profibrinolysin by serum fibrinolysokinase. Proc. Soc. exp. Biol. (N. Y.) 1951, 78, 184.

16. Mullertz, S., and Lassen, M. An activator system in blood indispensable for formation of plasmin by streptokinase. Proc. Soc. exp. Biol. (N. Y.) 1953, 82, 264.

17. Ratnoff, O. D., and Rosenblum, J. M. The role of Hageman factor in the initiation of clotting by glass. J. Lab. clin. Med. 1957, 50, 941. 